\title{
Propionibacterium microaerophilum sp. nov., a microaerophilic bacterium isolated from olive mill wastewater
}

\author{
${ }^{1}$ Laboratoire de \\ microbiologie IRD, \\ IFR-BAIM, Universités \\ de Provence et de la \\ Méditerranée, ESIL case \\ 925, 13288 Marseille Cedex \\ 9 , France \\ 2 School of Biomolecular \\ and Biomedical Sciences, \\ Faculty of Science, Griffith \\ University, Brisbane, \\ Queensland 4111, \\ Australia
}

\author{
Marina Koussémon, ${ }^{1}$ Yannick Combet-Blanc, ${ }^{1}$ Bharat K. C. Patel, ${ }^{2}$ \\ Jean-Luc Cayol, ${ }^{1}$ Pierre Thomas, ${ }^{1}$ Jean-Louis Garcia ${ }^{1}$ \\ and Bernard Ollivier ${ }^{1}$ \\ Author for correspondence: Yannick Combet-Blanc. Tel: +33 491828573 . Fax: +3349182 8570. \\ e-mail: combet@esil.univ-mrs.fr
}

\begin{abstract}
A new Gram-positive, facultative anaerobic, microaerophilic bacterium, designated strain $\mathrm{M5}^{\top}$, was isolated from a decantation reservoir of olive mill wastewater. The cells were rod-shaped, non-motile, non-spore-forming and catalase-negative. Growth occurred at pH ranging from 4.5 to 9.5, with optimum growth at 7.0. The optimum temperature for growth was around $30{ }^{\circ} \mathrm{C}$. Although growth occurred under anaerobic and aerobic conditions, the optimum $\mathrm{O}_{2}$ concentration for growth was determined as $5 \%$ in the gas phase of the culture. During anaerobic growth, glucose or lactate were mainly fermented to propionate, acetate and $\mathrm{CO}_{2}$. In the presence of $\mathrm{O}_{2}$ (more than $2 \%$ ), glucose was oxidized completely to $\mathrm{CO}_{2}$. The $\mathrm{G}+\mathrm{C}$ content of the DNA was $67.7 \pm 0.6 \mathrm{~mol} \%$ and 165 rRNA gene analysis revealed that the new isolate belonged to the cluster of ' dairy' propionibacteria, Propionibacterium acidipropionici being its closest phylogenic relative ( $97 \cdot 5 \%$ similarity). However, the level of DNA relatedness between strain $\mathrm{M5}^{\mathrm{T}}$ and $P$. acidipropionici was $\mathbf{5 6 . 2} \%$. Consequently, both the phenotypic (range of substrates used) and genotypic characteristics of strain $\mathrm{M5}^{\mathrm{T}}$ allow it to be assigned as a new species of the genus Propionibacterium, Propionibacterium microaerophilum sp. nov. The type strain is strain $\mathrm{M5}^{\top}$ ( $=\mathrm{CNCM}^{\mathrm{I}-2360^{\top}}=\mathrm{DSM}$ 13435').
\end{abstract}

Keywords: microaerophilic, anaerobe, propionic fermentation, taxonomy, phylogeny

\section{INTRODUCTION}

Olive oil production is a significant industry in most Mediterranean countries, and 1800 million tons are produced per year. This activity generates large volumes of effluent (20-30 million $\mathrm{m}^{3}$ year $^{-1}$ ), rich in organic matter $\left(420000\right.$ tons $\mathrm{BOD}_{5}$ year $^{-1}$, that is an important environmental pollutant (Balice et al., 1992). In this respect, several bioremediation programs dealing with olive mill wastewater have been undertaken during recent decades. Studies on the chemical composition revealed the presence of phenolic compounds, which represent the main source of pollution (Hamdi et al., 1992; Sayadi \& Ellouz, 1993). Phenolics include monomers (e.g. hydroxyquinone, gallate, sal-

The GenBank accession number for the $16 \mathrm{~S}$ rDNA sequence of strain $\mathrm{M}^{\mathrm{T}}$ is AF234623. icylate, protocatechuate and $p$-hydroxybenzoate) and condensed aromatics (e.g. soluble tannins, complex tannins, flavonoids, lignins, catechol-melanines and flavolanes) (Harborne, 1980). Besides phenolic compounds, olive mill effluents also contain other organic substances such as sugars, nitrogen compounds and organic acids. These compounds provide a large range of substrates for micro-organisms present in olive mill wastewater.

Whereas most microbiological studies have paid attention to aerobic and anaerobic populations of microorganisms from olive mill wastewater, no studies on microaerophiles have been reported so far. We report here the isolation of a new microaerophilic bacterium from an olive mill wastewater reservoir. This reservoir is a storage pond, approximately $2 \mathrm{~m}$ deep and $30 \mathrm{~m}^{3}$ in volume. The olive mill wastewater is stored in the reservoir for natural bioremediation before evacuation 
into a river. Since the reservoir was open to the air, it constituted a good ecosystem from which to seek microaerophilic bacteria.

\section{METHODS}

Origin of strains. Strain $\mathrm{M} 5^{\mathrm{T}}$ was isolated from an olive mill wastewater reservoir in Raphèle-les-Arles $(100 \mathrm{~km}$ northwest of Marseille) in the south of France. Samples were stored at $4{ }^{\circ} \mathrm{C}$ in serum bottles under anaerobic conditions under an atmosphere of $\mathrm{O}_{2}$-free $\mathrm{N}_{2}$. Propionibacterium acidipropionici DSM 20272, P. acidipropionici DSM 4900 ${ }^{\mathrm{T}}$, Propionibacterium jensenii DSM 20535 ${ }^{\mathrm{T}}$ and Propionibacterium thoenii DSM 20276 ${ }^{\mathrm{T}}$ were obtained from the DSMZ, Braunschweig, Germany.

Culture methods and media. Unless indicated otherwise, all media were boiled, dispensed under a stream of $\mathrm{O}_{2}$-free $\mathrm{N}_{2}$ into $100 \mathrm{ml}$ serum bottles $(20 \mathrm{ml}$ medium) or into Hungate tubes ( $5 \mathrm{ml}$ medium) and stored with $\mathrm{N}_{2}$ in the headspace. For the enrichment and purification procedures, a basal medium $(\mathrm{BM})$ was used that contained $\left(\mathrm{l}^{-1}\right.$ reverse-osmosis water): $0.6 \mathrm{~g} \mathrm{KH}_{2} \mathrm{PO}_{4}, 0.2 \mathrm{~g} \mathrm{MgCl}_{2} .6 \mathrm{H}_{2} \mathrm{O}, 1 \mathrm{~g} \mathrm{NH} \mathrm{Nl}_{4}, 1 \mathrm{~g}$ $\mathrm{NaCl}$ and $10 \mathrm{ml}$ trace-element solution (Balch et al., 1979). The effects of vitamins on growth were tested in BM supplemented with $10 \mathrm{mM}$ glucose and $0.8 \mathrm{ml}$ Balch vitamin solution $1^{-1}$ (Balch et al., 1979). For routine cultures and further characterization of strain $\mathrm{M}^{\mathrm{T}}$, YEM medium (basal medium supplemented with $0 \cdot 1$ g yeast extract $1^{-1}$ ) was used. $P$. acidipropionici, $P$. jensenii and $P$. thoenii were cultivated in PM medium containing $\left(1^{-1}\right.$ reverse-osmosis water $): 2 \mathrm{~g}$ $\mathrm{KH}_{2} \mathrm{PO}_{4}, 10 \mathrm{~g}$ bio-Trypcase (bioMérieux) and $10 \mathrm{~g}$ yeast extract. The $\mathrm{pH}$ of culture media was adjusted to 7.0 with a $10 \mathrm{M} \mathrm{NaOH}$ solution. Sterilization was performed by autoclaving at $110^{\circ} \mathrm{C}$ for $45 \mathrm{~min}$. Energy sources tested were injected into serum bottles and Hungate tubes from separate anaerobic stock solutions. Unless indicated otherwise, all experiments were conducted in duplicate at the optimum temperature for growth $\left(30^{\circ} \mathrm{C}\right)$ at $\mathrm{pH} 7 \cdot 0$ and under anaerobic conditions.

Enrichment and isolation procedure. Enrichment cultures were obtained by culture in deep agar (Weinberg et al., 1937). Hungate tubes containing $10 \mathrm{ml} \mathrm{BM}$ supplemented with 4 g agar $\mathrm{l}^{-1}, 5 \mathrm{mM}$ sodium benzoate and $10 \mathrm{mM}$ glucose were boiled for 10 min under a stream of $\mathrm{O}_{2}$-free $\mathrm{N}_{2}$ to purge the $\mathrm{O}_{2}$ dissolved in the medium. After cooling to approximately $40{ }^{\circ} \mathrm{C}, 0.5 \mathrm{ml}$ samples of olive mill wastewater were dispensed with a syringe into the tubes containing semi-solid medium, homogenized and cooled to room temperature under a stream of sterile air. The tubes were then incubated at $30{ }^{\circ} \mathrm{C}$. After approximately 1 week of incubation, significant growth was obtained at about $2.5 \mathrm{~cm}$ from the surface, suggesting the presence of microaerophilic microorganisms. An aliquot $(0.5 \mathrm{ml}$ from this deep semi-solid culture) was taken by using a sterile syringe. After subculturing twice under the same conditions, a semi-solid aliquot of this enrichment culture was serially diluted in liquid BM. Thereafter, each dilution was spread on agar plates containing the same BM supplemented with $10 \mathrm{mM}$ glucose, $5 \mathrm{mM}$ sodium benzoate and $20 \mathrm{~g}$ agar $1^{-1}$. The inoculated agar plates were placed in jars under an atmosphere of $\mathrm{N}_{2} / \mathrm{O}_{2}(95: 5 \%, \mathrm{v} / \mathrm{v})$ at atmospheric pressure and incubated at $30^{\circ} \mathrm{C}$ for $6 \mathrm{~d}$. Single colonies were picked from the plates and subcultured at least twice on agar plates under the same conditions. In the last purification step, single colonies obtained from the plates were serially diluted in Hungate tubes containing $5 \mathrm{ml}$ liquid $\mathrm{BM}$ and $10 \mathrm{mM}$ glucose as an energy source. The gas atmosphere was $\mathrm{N}_{2} / \mathrm{O}_{2}$ $(95: 5 \%, \mathrm{v} / \mathrm{v})$. Incubation was performed at $30{ }^{\circ} \mathrm{C}$ without agitation for 1 week. The procedure was repeated until only one type of colony was observed.

Sporulation and heat-resistance tests. The presence or absence of spores was examined microscopically. In the absence of apparent spore formation, the presence of heatresistant or heat-tolerant cells was tested. For this purpose, bacterial cultures were grown at $30{ }^{\circ} \mathrm{C}$ in YEM medium with $10 \mathrm{mM}$ glucose. After 2, 7 and $14 \mathrm{~d}$ of incubation at $30^{\circ} \mathrm{C}$, the cells were observed with a phase-contrast microscope and the viability of cells was checked by subculturing. Duplicate cultures were then heated at $80{ }^{\circ} \mathrm{C}$ for 5 and 10 min, subcultured into fresh medium (20\% inoculum) and incubated for $48 \mathrm{~h}$ at $30^{\circ} \mathrm{C}$.

Analytical techniques. Bacterial growth was monitored by measuring the increase in turbidity at $580 \mathrm{~nm}$ with a spectrophotometer (Shimadzu UV 160A). Glucose and fermentation end-products were determined by HPLC using a pump (Spectra Series P100; Spectra-Physics), an automatic sampler (Spectra Series AS100), an Aminex HPX 87H $(300 \times 7.8 \mathrm{~mm})$ column (Bio-Rad), a differential refractometer detector (Shimadzu RID $6 \mathrm{~A}$ ) and an integrator (Shimadzu C-R 6 A Chromatopac). An aliquot of $20 \mu \mathrm{l}$ cellfree supernatant was injected into the column, which was maintained at $35^{\circ} \mathrm{C}$. A $2.5 \mathrm{mM} \mathrm{H}_{2} \mathrm{SO}_{4}$ solution was used as solvent with a flow rate of $0.6 \mathrm{ml} \mathrm{min}-1$. Oxygen, $\mathrm{H}_{2}, \mathrm{~N}_{2}$ and $\mathrm{CO}_{2}$ levels were determined with a GC (Chrompack CP $9000)$ equipped with a thermal conductivity detector and a double column. The first column $(1.5 \mathrm{~m} \times 2 \mathrm{~mm})$ was packed with silica gel $60-80$ mesh. The second column $(1.5 \mathrm{~m}$ $\times 2 \mathrm{~mm}$ ) was packed with a molecular sieve $5 \AA$ 60-80 mesh. The carrier gas was helium $\left(15 \mathrm{ml} \mathrm{min}^{-1}\right)$. Temperatures were: injector, $50{ }^{\circ} \mathrm{C}$; columns, $50{ }^{\circ} \mathrm{C}$; detector, $150^{\circ} \mathrm{C}$. Gases were sampled and injected $(0.5 \mathrm{ml})$ using $1 \mathrm{ml}$ syringes.

DNA was isolated from exponentially growing cells and the $\mathrm{G}+\mathrm{C}$ content was determined at the DSMZ by HPLC, as described previously (Cashion et al., 1977; Mesbah et al., 1989). Temperature, $\mathrm{pH}$ and $\mathrm{NaCl}$ profiles for growth were determined under anaerobic conditions using YEM medium containing glucose as an energy source. The temperature range was determined by using thermostatically controlled water baths. Determination of the $\mathrm{pH}$ profile was performed in a 21 fermenter (Labo 2000 ; Interscience) at $30{ }^{\circ} \mathrm{C}$ with stirring at 200 r.p.m. The $\mathrm{pH}$ was controlled by the addition of $0.5 \mathrm{M} \mathrm{NaOH}$ with an automatic $\mathrm{pH}$ regulator (Interscience). Catalase activity was tested by resuspending cells, harvested by centrifugation of $1.5 \mathrm{ml}$ culture, in $3 \% \mathrm{H}_{2} \mathrm{O}_{2}$. The culture was incubated for $5 \mathrm{~d}$ in the presence of $5 \% \mathrm{O}_{2}$ in the gas phase. Nitrate reduction was determined by using Griess' reagent (Sigma). $\mathrm{H}_{2} \mathrm{~S}$ was measured photometrically as colloidal $\mathrm{CuS}$ after reacting with a mixture containing $50 \mathrm{mM} \mathrm{HCl}^{\text {and }} 5 \mathrm{mM} \mathrm{CuSO}_{4}$ (Cord-Ruwisch, 1985). The fermentation patterns were determined in triplicate by using the API $50 \mathrm{CH}$ kit (bioMérieux) with YEM medium supplemented with $2 \mathrm{~g} \mathrm{KH}_{2} \mathrm{PO}_{4} \mathrm{l}^{-1}$ for strain $\mathrm{M}^{\mathrm{T}}$ and PM medium for $P$. acidipropionici, $P$. jensenii and $P$. thoenii; both media were supplemented with $0.018 \%$ phenol red, used as a $\mathrm{pH}$ indicator. Anaerobic conditions were ensured by filling wells with paraffin oil.

Effects of $\mathrm{O}_{2}$ on growth and product fermentation patterns. Experiments were performed in $100 \mathrm{ml}$ serum bottles containing $20 \mathrm{ml}$ YEM medium supplemented with $20 \mathrm{mM}$ of glucose, with $\mathrm{N}_{2}$ in the headspace. Bottles were inoculated (5\% inoculum) with exponentially grown cultures of strain $\mathrm{M}^{\mathrm{T}}$ and various volumes of sterile air were added to the gas 

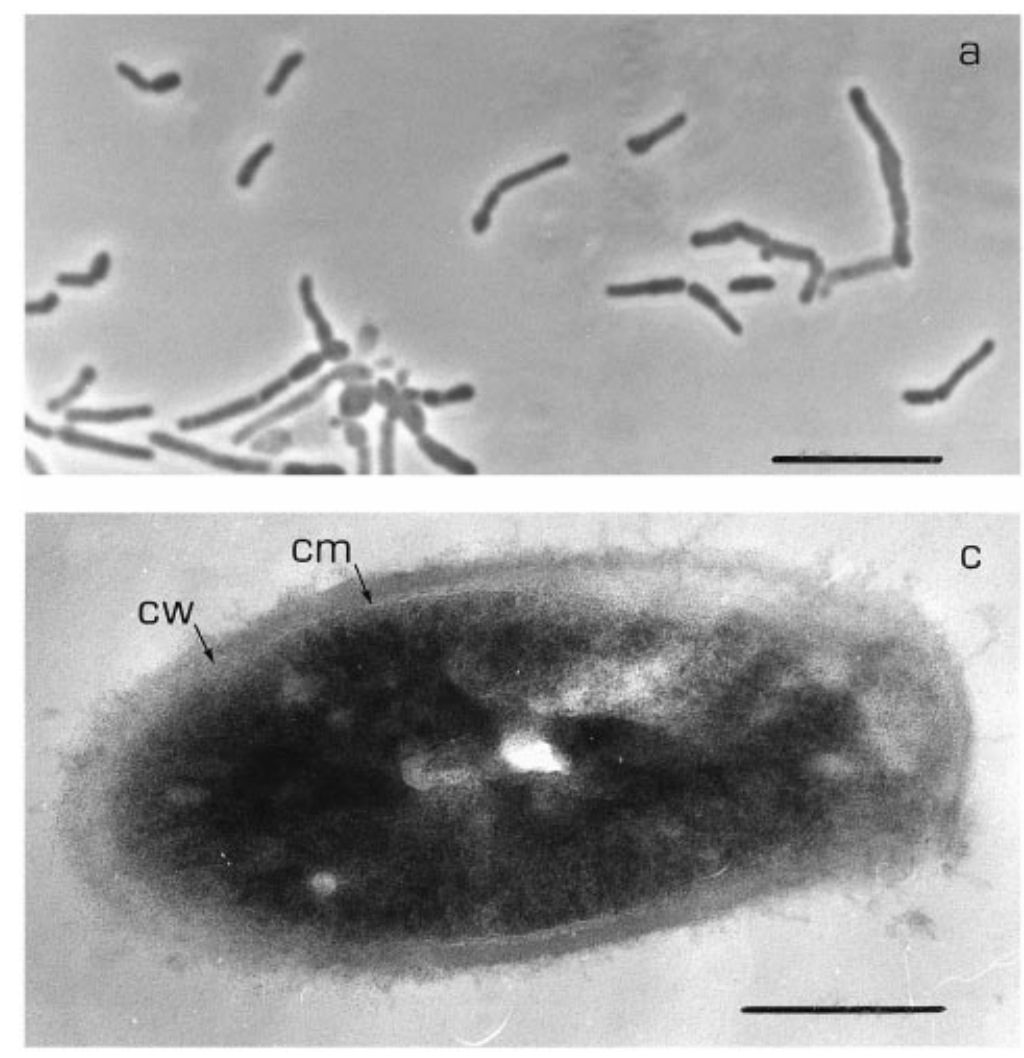

b

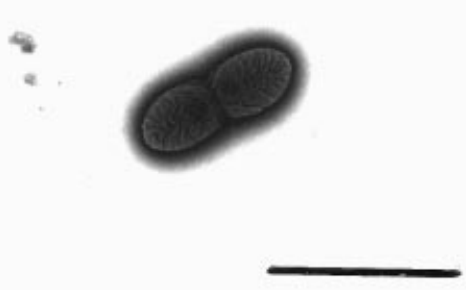

Fig. 1. (a) Phase-contrast photomicrograph of strain $M 5^{\top}$ from a culture in stationary phase. Bar, $10 \mu \mathrm{m}$. (b) Electron microscope photomicrograph of negatively stained cells of strain $\mathrm{M5}^{\top}$. Bar, $2 \mu \mathrm{m}$. (c) Electron microscope photomicrograph of an ultrathin section of strain $\mathrm{M}^{\top}{ }^{\top}$, showing the cell wall structure. $\mathrm{cm}$, Cytoplasmic membrane; $\mathrm{cw}$, cell wall. Bar, $0.2 \mu \mathrm{m}$. phase. The cultures were incubated at $30{ }^{\circ} \mathrm{C}$ with 200 r.p.m. agitation. The gas phase was replaced every $12 \mathrm{~h}$ throughout the course of the experiment. Growth and metabolic endproducts were monitored at $24 \mathrm{~h}$ intervals by turbidity measurements $(580 \mathrm{~nm})$ and HPLC analysis, respectively. All the experiments were conducted in duplicate and repeated at least once.

Morphological characteristics. Morphological properties were determined by phase-contrast microscopy, using slides coated with a thin layer $(0.5 \mathrm{~mm})$ of purified agar (Difco). For electron microscopy, preparations were negatively stained with $1 \%$ sodium phosphotungstate $(\mathrm{pH} 7 \cdot 2)$. For preparation of thin sections, exponentially grown cells were centrifuged and fixed for $0.5 \mathrm{~h}$ in $4 \%(\mathrm{w} / \mathrm{v})$ glutaraldehyde prepared in $0.025 \mathrm{M} \mathrm{HCl} /$ cacodylate buffer ( $\mathrm{pH} \mathrm{6.0)}$. The cells were then washed in the same buffer containing $0.3 \mathrm{M}$ sucrose and post-fixed in osmium tetroxide prepared in the same buffer with $0.25 \mathrm{M}$ sucrose. After fixation, the cells were washed with water, embedded in $2 \%$ agarose and stained with $4 \%$ uranyl acetate. The agar was cut into small cubes, dehydrated in acetone and embedded in Araldite. Thin sections were stained with $5 \%$ uranyl acetate for $20 \mathrm{~min}$ and with $2 \%$ lead citrate for $10 \mathrm{~min}$. Micrographs were taken with a Hitachi model H600 electron microscope at an accelerating voltage of $75 \mathrm{kV}$.

DNA-DNA hybridization. DNA was isolated by the method of Cashion et al. (1977). DNA-DNA hybridization was performed at the DSMZ as described by De Ley et al. (1970), with the modifications of Escara \& Hutton (1980) and Huß et al. (1983), using a Gilford System model 2600 spectrophotometer equipped with a Gilford model 2527-R thermoprogrammer and plotter. Renaturation rates were computed with the TRANSFER.BAS program of Jahnke \& Bahnweg (1986) and Jahnke (1992).
DNA extraction and amplification of 16S rRNA gene. DNA was extracted from the isolate as described previously (Andrews \& Patel, 1996; Redburn \& Patel, 1993). The universal primers Fd1 and Rd1 were used to obtain a PCR product of approximately $1.5 \mathrm{~kb}$, corresponding to positions 8-1542 (Escherichia coli numbering) of the 16S rDNA (Winker \& Woese, 1991). A $50 \mu \mathrm{l}$ reaction contained 1-20 ng genomic DNA, $1 \mu \mathrm{M}$ of each primer, $5 \mu \mathrm{l} 10 \times$ buffer, $200 \mu \mathrm{M}$ dNTPs, $3.5 \mathrm{mM} \mathrm{MgCl}_{2}$ and $2.5 \mathrm{U}$ Taq polymerase (Promega). PCR was performed by an initial denaturation at $94{ }^{\circ} \mathrm{C}$ for $4 \mathrm{~min}$, followed by 30 cycles of annealing at $55^{\circ} \mathrm{C}$ for $2 \mathrm{~min}$, extension at $72^{\circ} \mathrm{C}$ for $4 \mathrm{~min}$ and denaturation at $94^{\circ} \mathrm{C}$ for $1 \mathrm{~min}$ and finally an extension cycle of $55^{\circ} \mathrm{C}$ for $2 \mathrm{~min}$ and $72^{\circ} \mathrm{C}$ for $20 \mathrm{~min}$.

Direct sequencing of PCR products. PCR products were purified using a QIAquick kit (Qiagen). The DNA concentration of the purified PCR product was estimated by comparison with a Low-Mass ladder (Gibco-BRL) on an agarose gel containing ethidium bromide. QIAquick-purified PCR products were sequenced using the ABI PRISM Dye Terminator cycle sequencing kit, containing AmpliTaq FS DNA polymerase, and an ABI 373A sequencer. A $10 \mu 1$ reaction contained $35 \mathrm{ng}$ PCR product, $4 \mu \mathrm{l}$ cycle-sequencing reaction mix, $3 \cdot 2$ pmol primer and $2 \cdot 5 \mu \mathrm{g}$ BSA. Thermal cycling was performed using a RapidCycler (Idaho Technology) at a temperature transition slope of 2 , an initial denaturation of $94^{\circ} \mathrm{C}$ for $15 \mathrm{~s}$ and then 25 cycles of denaturation at $94{ }^{\circ} \mathrm{C}$ for $0 \mathrm{~s}$, annealing at $50{ }^{\circ} \mathrm{C}$ for $10 \mathrm{~s}$ and extension at $60{ }^{\circ} \mathrm{C}$ for $3 \mathrm{~min}$.

Sequence alignments and phylogenetic inferences. The new sequence was aligned to an almost full length consensus $16 \mathrm{~S}$ rRNA gene sequence, assembled and checked for accuracy manually using the alignment editor ae2 (Maidak et al., 1996). These were compared with other sequences in the 
GenBank database (Benson et al., 1993) using BLAST (Altschul et al., 1997) and in the Ribosomal Database Project, version 7.0, using SIMILARITY_RANK and SUGGEST_ TREE (Maidak et al., 1996). Pairwise evolutionary distances based on 1253 unambiguous nucleotides were computed by using the DNADIST (Jukes \& Cantor, 1969) and NEIGHBOR programs that form part of the PHYLIP suite of programs (Felsenstein, 1993).

\section{RESULTS}

\section{Enrichment and isolation}

In the initial enrichment cultures in deep agar, a ring or disc of growth was formed at about $2.5 \mathrm{~cm}$ under the surface within 1 week of incubation at $30^{\circ} \mathrm{C}$. The disc was white and 1-2 mm thick. After two subcultures under the same conditions, an aliquot of the disc was spread on agar plates and incubated under $\mathrm{N}_{2} / \mathrm{O}_{2}$ $(95: 5 \%, \mathrm{v} / \mathrm{v})$. After 1 week, single colonies were obtained and subcultured once again under the same conditions. One isolate, designated strain $\mathrm{M}^{\mathrm{T}}$, was used for further characterization.

\section{Colony and cell morphology}

Colonies obtained after 1 week of incubation on solid YEM medium under microaerophilic conditions $\left(95: 5 \% \mathrm{~N}_{2} / \mathrm{O}_{2}, \mathrm{v} / \mathrm{v}\right)$ were white, lens-shaped with smooth edges and $2-3 \mathrm{~mm}$ in diameter. Cells of strain $M 5^{\mathrm{T}}$ were single, or in short chains in aged cultures, pleomorphic rods $(0.5-0.7 \mu \mathrm{m}$ wide and $2-3.5 \mu \mathrm{m}$ long) with rounded ends (Fig. 1a,b). They exhibited no motility under phase-contrast microscope examination. Ultrathin electron microscope sections revealed a thick, not very dense, Gram-positive cell envelope (Fig. 1c). Spores were not observed at any stage of growth. Cultures incubated at $80^{\circ} \mathrm{C}$ for 5 or $10 \mathrm{~min}$ could not be subcultured, indicating the absence of spores or heat-resistant forms.

\section{Growth and metabolic properties}

Strain $\mathrm{M} 5^{\mathrm{T}}$ grew on BM containing glucose or lactate as the sole energy source in the absence of growth factors including vitamins, amino acids and peptides. However, growth was stimulated in the presence of yeast extract. Addition of vitamins had no significant effect on growth or cellular yield. During fermentation of glucose, strain $\mathrm{M} 5^{\mathrm{T}}$ produced mainly propionate, acetate and $\mathrm{CO}_{2}$ as end-products, but traces of succinate and formate were also detected. $\mathrm{No}_{2}$ was detected. Otherwise, with more than $2 \% \mathrm{O}_{2}$ in the gas phase, glucose was oxidized completely to $\mathrm{CO}_{2}$. However, under anaerobic conditions, strain $\mathrm{M} 5^{\mathrm{T}}$ did not grow with propionate, acetate, succinate or formate as the energy source. The fermentation balance on

Table 1. Comparison of sugar fermentation by strain $\mathrm{M}^{\top}$ and phylogenetically related Propionibacterium species

Fermentation patterns for the four strains were determined in this study. Sugar utilization was assessed out by using API $50 \mathrm{CH}$ strips with phenol red as $\mathrm{pH}$ indicator. A drop of oil was added to each cupule after inoculation to create anoxic conditions. Strips were incubated at $30^{\circ} \mathrm{C}$ for $4 \mathrm{~d}$, after which results were recorded. The other sugars of the API $50 \mathrm{CH}$ strip gave the same fermentation profiles for all four strains.

\begin{tabular}{|c|c|c|c|c|}
\hline Carbon source & Strain $\mathbf{M 5}^{\mathrm{T}}$ & $\begin{array}{c}\text { P. acidipropionici DSM } \\
20272\end{array}$ & $\begin{array}{c}\text { P. jensenii DSM } \\
20535^{\mathrm{T}}\end{array}$ & $\begin{array}{c}\text { P. thoenii DSM } \\
\text { 20276 }^{\mathrm{T}}\end{array}$ \\
\hline D-Arabinose & - & + & - & - \\
\hline L-Arabinose & + & + & - & - \\
\hline D-Xylose & - & + & - & - \\
\hline L-Sorbose & + & - & - & - \\
\hline Rhamnose & + & + & - & - \\
\hline Inositol & + & + & + & - \\
\hline Mannitol & + & + & + & - \\
\hline Sorbitol & + & + & - & + \\
\hline Methyl $\alpha$-D-mannoside & - & - & - & + \\
\hline Methyl $\alpha$-D-glucoside & + & + & - & + \\
\hline$N$-Acetylglucosamine & + & + & - & + \\
\hline Amygdalin & - & + & + & - \\
\hline Lactose & - & + & - & + \\
\hline Melibiose & - & + & + & - \\
\hline Melezitose & + & + & + & - \\
\hline D-Raffinose & - & + & + & - \\
\hline Starch & + & + & - & + \\
\hline Glycogen & + & + & - & - \\
\hline D-Fucose & - & + & - & - \\
\hline Gluconate & + & + & + & - \\
\hline Aesculin hydrolysis & - & + & + & + \\
\hline
\end{tabular}




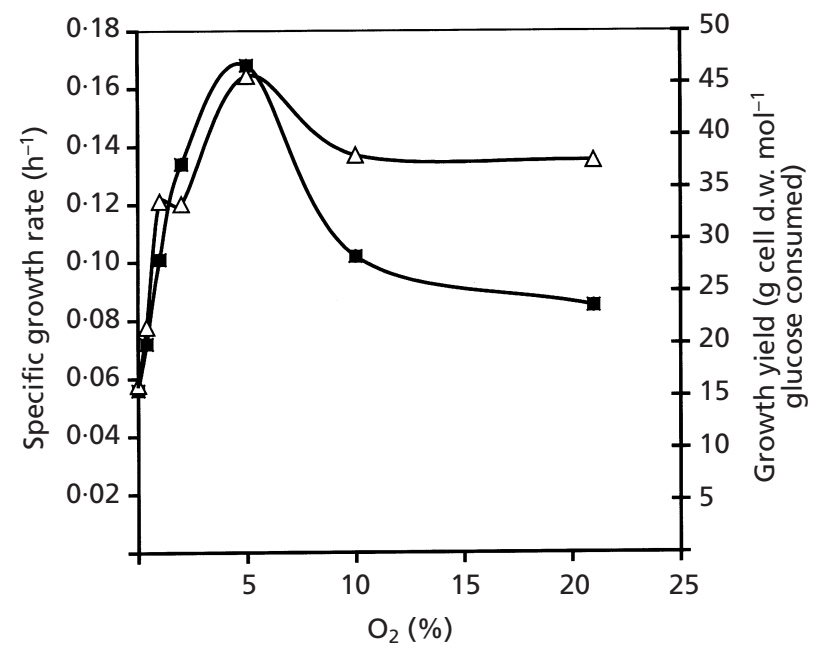

Fig. 2. Effect of oxygen concentration (\%) on the specific growth rate $(\boldsymbol{\square})$ and growth yield on glucose $(\triangle)$ of Propionibacterium microaerophilum $\mathrm{M}^{\top}$.

glucose, accounting for a level of carbon recovery of $87.3 \%$, was 3.0 glucose $\rightarrow 4.2$ propionate +1.8 acetate $+1.8 \mathrm{CO}_{2}$. On lactate, accounting for a level of carbon recovery of $98.67 \%$, the fermentation balance was $3 \cdot 0$ lactate $\rightarrow 2 \cdot 1$ propionate +0.9 acetate +0.9 $\mathrm{CO}_{2}$. The optimum temperature for growth of strain $\mathrm{M} 5^{\mathrm{T}}$ was $30^{\circ} \mathrm{C}$, with growth occurring at temperatures ranging from 20 to $45^{\circ} \mathrm{C}$. The organism grew at $\mathrm{pH}$ values ranging from $4 \cdot 5$ to $9 \cdot 5$; the optimum $\mathrm{pH}$ was $7 \cdot 0$. The optimum $\mathrm{NaCl}$ concentration for growth was $5 \mathrm{~g}^{-1}$; growth occurred at concentrations ranging from 0 to $20 \mathrm{~g} \mathrm{l}^{-1}$.

Sulfate, thiosulfate, sulfite, elemental sulfur and fumarate were not used as terminal electron acceptors. Nitrate was reduced into $\mathrm{N}_{2}$. The range of carbohydrates catabolized was determined with the API 50 $\mathrm{CH}$ kit (bioMérieux). Among the $\mathrm{pH}$ indicators tested for growth (bromthymol blue, bromcresol purple, phenol red) of Propionibacterium strains, only phenol red did not inhibit growth of any of the strains studied. It was therefore chosen for further growth studies. The range of carbohydrates used by each strain is reported in Table 1.

\section{Effect of $\mathrm{O}_{2}$ on growth and catabolism products of glucose}

Growth rate $\left(\mu_{\max }\right)$ and cellular yield $\left(\mathrm{Y}_{\mathrm{x} / \mathrm{s}}\right)$ values (Fig. 2) showed that strain $\mathrm{M}^{\mathrm{T}}$ grew at $\mathrm{O}_{2}$ concentrations ranging from 0 (anaerobic conditions) to $21 \%$, the optimum $\mathrm{O}_{2}$ concentration for growth being $5 \%$.

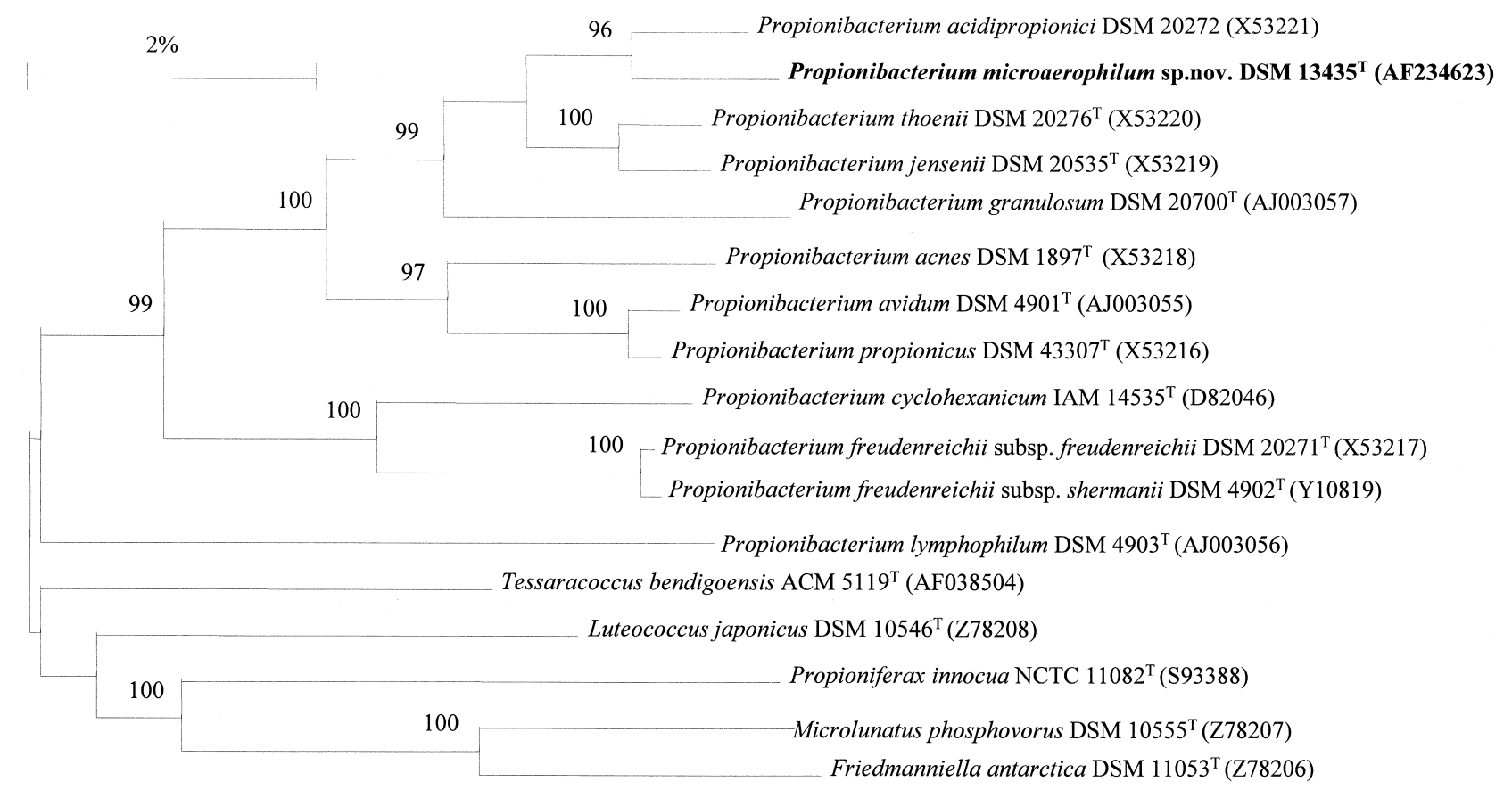

Fig. 3. The position of Propionibacterium microaerophilum $M 5^{\top}$ in relation to its phylogenetic relatives in the family Propionibacteriaceae. Strain numbers from culture collections and their corresponding 16S rRNA gene sequence accession numbers (in parentheses) extracted from GenBank/EMBL are shown. Phylogenetic analysis was performed on 1196 unambiguous nucleotides using the DNADIST and NEIGHBOR programs that form part of the PHYLIP suite of software. Bar, 2 nucleotide changes per 100 nucleotides. Abbreviations: T, type strain; DSM, Deutsche Sammlung von Mikroorganismen und Zellkulturen; ACM, Australian Collection of Microorganisms; IAM, Institute of Applied Microbiology; and NCTC, National Collection of Type Cultures. 
Below $2 \%$, propionate and acetate were detected. For $\mathrm{O}_{2}$ concentrations higher than $2 \%$, glucose was oxidized completely to $\mathrm{CO}_{2}$. However, strain $\mathrm{M}^{\mathrm{T}}$ did not possess detectible catalase activity.

\section{S rDNA sequence analysis and DNA relatedness}

The mean of triplicate determinations of $\mathrm{G}+\mathrm{C}$ content of strain M5 $5^{\mathrm{T}}$ DNA was $67.7 \pm 0.6 \mathrm{~mol} \%$ (HPLC). Using eight primers, a nearly complete sequence was determined consisting of 1524 bases of the $16 \mathrm{~S}$ rRNA gene of isolate $\mathrm{M} 5^{\mathrm{T}}$. The sequence of positions 8-1524 (E. coli numbering; Winker \& Woese, 1991) was aligned with sequences representative of the family Propionibacteriaceae. Phylogenetic analysis showed that strain M5 $^{\mathrm{T}}$ was related to species of the genus Propionibacterium, P. acidipropionici being its closest relative (similarity of $97.5 \%$ ) (Fig. 3). The level of DNA relatedness between strain $\mathrm{M}^{\mathrm{T}}$ and $P$. acidipropionici DSM $4900^{\mathrm{T}}$, its closest relative, was $56 \%$.

\section{DISCUSSION}

Strain $\mathrm{M} 5^{\mathrm{T}}$, isolated from olive mill wastewater, was a mesophilic, catalase-negative, facultative anaerobe and microaerophilic bacterium. The results of $16 \mathrm{~S}$ rRNA gene sequence studies indicated that strain M5 ${ }^{\mathrm{T}}$ is phylogenetically related to the Propionibacterium species group and that it is closely related to $P$. acidipropionici DSM 20272, with 97.5\% sequence similarity. Using the multiplex-PCR method based on 16S-23S ribosomal spacer DNA sequences, Meile et al. (1999) showed that the phylogeny of Propionibacterium species was similar to that established with only $16 \mathrm{~S}$ rRNA, even if the distances were quite different. DNA-DNA hybridization experiments between strain $\mathrm{M}^{\mathrm{T}}$ and its closest relative, $P$. acidipropionici, showed reassociation of only $56 \%$. Phenotypically, cells of strain $\mathrm{M}^{\mathrm{T}}$ were single or in short chains, pleomorphic rods, non-motile, non-sporeforming, with a Gram-positive cell envelope profile. The isolate had a DNA $\mathrm{G}+\mathrm{C}$ content of 67.7 $\pm 0.6 \mathrm{~mol} \%$. The strain required no complex nitrogen nutrients such as yeast extract, amino acids or peptides for growth. It could grow with only ammonium salts as the nitrogen source. Yeast extract improved the growth of strain $\mathrm{M}^{\mathrm{T}}$, whereas the presence of other growth factors such as pantothenate, biotin or thiamin had no effect on growth. Under anaerobic conditions, the strain produced large amounts of propionate, acetate and $\mathrm{CO}_{2}$ during fermentation of glucose or lactate. Under these conditions, the stoichiometric balances of glucose and lactate fermentations were consistent with the glucose and lactate fermentation pathways described for members of the genus Propionibacterium (Wood, 1981). Furthermore, the ranges of temperature, $\mathrm{pH}$ and $\mathrm{NaCl}$ concentration for growth and the morphological and physiological characteristics of strain $M 5^{\mathrm{T}}$ were also consistent with the general description of the genus Propionibacterium (Cummins \& Johnson, 1986). The phenotypic characteristics of strain $\mathrm{M} 5^{\mathrm{T}}$ supported the phylogenic results and confirmed that it belongs to the genus Propionibacterium.

Several phenotypic differences were observed between strain $\mathrm{M} 5^{\mathrm{T}}$ and other species of the genus Propionibacterium. It has been reported that pantothenate is required for growth of all Propionibacterium species. The presence of thiamin, nicotinamide, oleate and biotin improved the growth of propionibacteria in general, $p$-aminobenzoic acid being required by some strains (Delwiche, 1949; Ferguson \& Cummins, 1978; Holland et al., 1979; Cummins \& Johnson, 1986). In contrast to the auxotrophic behaviour of Propionibacterium species, strain $\mathrm{M} 5^{\mathrm{T}}$ did not require growth factors and was therefore prototrophic. Strain M5 ${ }^{\mathrm{T}}$ was catalase-negative, whereas the propionibacteria are generally catalase-positive, with the exception of Propionibacterium propionicus (Schaal, 1986; Charfreitag et al., 1988) and Propionibacterium cyclohexanicum (Kusano et al., 1997). Moreover, strain $M 5^{\mathrm{T}}$ reduced nitrate to $\mathrm{N}_{2}$, whereas other Propionibacterium species reduce nitrate only to nitrite (Table 2). While strain $M 5^{\mathrm{T}}$ was microaerophilic, growing better in an atmosphere containing $5 \%$ oxygen, Propionibacterium species are generally considered as anaerobic to aerotolerant, preferring anaerobic conditions for growth (Cummins \& Johnson, 1986). Propionibacterium avidum and Propionibacterium granulosum are the only two current species of Propionibacterium described as microaerophilic, and $P$. propionicus was described as facultatively anaerobic (Cummins \& Johnson, 1986; Schaal, 1986; Charfreitag et al., 1988). In the presence of $\mathrm{O}_{2}$, during the growth of strain $\mathrm{M}^{\mathrm{T}}$, the energy source (glucose or lactate) was oxidized completely to $\mathrm{CO}_{2}$. Moreover, the cellular yield of strain $\mathrm{M}^{\mathrm{T}}$ in the presence of $5 \% \mathrm{O}_{2}$ was higher than under anaerobic conditions, suggesting that strain $\mathrm{M}^{\mathrm{T}}$ used $\mathrm{O}_{2}$ as an electron acceptor, generating energy through oxidation of the energy source. Although it has been confirmed that several Propionibacterium species possess the components of a typical aerobic electron transport chain, including membrane-bound dehydrogenase and cytochromes (Sone, 1972; De Vries et al., 1977; Pritchard et al., 1977; Ye et al., 1999), the metabolic pathways of propionibacteria growing under aerobic conditions are still not clear. Understanding of the metabolic pathways of strain $\mathrm{M}^{\mathrm{T}}$ that generate ATP in the presence of $\mathrm{O}_{2}$ will require further specific studies.

More accurate definitions are needed to qualify the ' $\mathrm{O}_{2}$-bacteria' relationship. Up to now, five terms have commonly been used to qualify the phenotype of bacteria according to their requirements for and tolerance and sensitivity to oxygen: 'aerobe', 'facultative anaerobe', 'aerotolerant anaerobe', 'microaerophile' and 'strict anaerobe' (Stanier et al., 1976; Marty et al., 1988). Microaerophiles are described as requiring $\mathrm{O}_{2}$ as the terminal electron acceptor, but growing exclusively or best at $\mathrm{O}_{2}$ levels below atmospheric concentrations $\left(21 \% \mathrm{O}_{2}\right)$. However, some 
Taxa are identified as: 1 , strain $\mathrm{M} 5^{\mathrm{T}} ; 2$, P. acidipropionici $; 3$, P. jensenii $; 4$, P. thoenii; 5 , P. acnes $; 6$, P. avidum; 7 , P. granulosum; 8 , Propionibacterium lymphophilum; 9 , P. propionicus; 10 , P. cyclohexanicum; 11, P. freudenreichii. Data were taken from this study (strain M5T), Cummins \& Johnson (1986) $(P$. acidipropionici, P. jensenii, $P$. thoenii, P. acnes, P. avidum, P. granulosum and P. lymphophilum), Charfreitag et al. (1988) and Schaal (1986) (P. propionicus) or Kusano et al. (1997) (P. freudenreichii) unless otherwise indicated. Characters are scored as: + , positive; $\mathrm{d}+, 40-90 \%$ of strains are positive; $\mathrm{d}-, 10-40 \%$ of strains are positive; $\mathrm{d}, 11-89 \%$ of strains are positive; - , negative. ND, No data available.

\begin{tabular}{|c|c|c|c|c|c|c|c|c|c|c|c|}
\hline Characteristic & 1 & 2 & 3 & 4 & 5 & 6 & 7 & 8 & 9 & 10 & 11 \\
\hline Habitat & $\begin{array}{l}\text { Olive mill } \\
\text { wastewater }\end{array}$ & $\begin{array}{l}\text { Dairy } \\
\text { products }\end{array}$ & $\begin{array}{l}\text { Dairy } \\
\text { products }\end{array}$ & $\begin{array}{l}\text { Cheese and } \\
\text { other dairy } \\
\text { products }\end{array}$ & $\begin{array}{l}\text { Human skin, } \\
\text { intestinal contents, } \\
\text { blood, pus }\end{array}$ & $\begin{array}{l}\text { Infected sinuses, } \\
\text { submaxillary } \\
\text { abscesses }\end{array}$ & $\begin{array}{l}\text { Human skin, blood, } \\
\text { intestinal contents }\end{array}$ & $\begin{array}{l}\text { Urinary tract } \\
\text { infection }\end{array}$ & $\begin{array}{l}\text { Lachrymal } \\
\text { canaliculitis }\end{array}$ & $\begin{array}{l}\text { Spoiled orange } \\
\text { juice }\end{array}$ & $\begin{array}{l}\text { Raw milk, } \\
\text { Swiss cheese and } \\
\text { other dairy products }\end{array}$ \\
\hline Catalase & - & $d+$ & $d+$ & + & $d+$ & + & + & $d+$ & - & - & + \\
\hline $\begin{array}{l}\text { Aesculin } \\
\text { hydrolysis }\end{array}$ & - & + & + & + & - & + & - & - & - & + & + \\
\hline $\begin{array}{l}\text { L-Sorbose } \\
\text { fermentation }\end{array}$ & + & $-^{*}$ & $-*$ & $-*$ & - & - & - & $\begin{array}{lll}- & \\
- & \end{array}$ & $\begin{array}{lll}- & - \\
-1\end{array}$ & - & - \\
\hline $\begin{array}{l}\text { Oxygen } \\
\text { tolerance }\end{array}$ & $\begin{array}{l}\text { Microaerophilic } \\
\text { facultative anaerobe }\end{array}$ & $\begin{array}{r}\text { Anaerobic to } \\
\text { aerotolerant }\end{array}$ & $\begin{array}{r}\text { Anaerobic to } \\
\text { aerotolerant }\end{array}$ & Anaerobic & $\begin{array}{r}\text { Anaerobic to } \\
\text { aerotolerant }\end{array}$ & $\begin{array}{l}\text { Microaerophilic } \\
\text { facultative anaerobe }\end{array}$ & $\begin{array}{r}\text { Anaerobic to } \\
\text { aerotolerant }\end{array}$ & Anaerobic & $\begin{array}{c}\text { Facultative } \\
\text { anaerobe }\end{array}$ & Aerotolerant & $\begin{array}{r}\text { Anaerobic to } \\
\text { aerotolerant }\end{array}$ \\
\hline $\begin{array}{l}\text { Nitrate reduction } \\
\text { to nitrite }\end{array}$ & Reduction to $\mathrm{N}_{2}$ & + & - & - & $\mathrm{d}+$ & - & - & d & + & - & d \\
\hline $\begin{array}{l}\text { Toxicity of } \\
\text { bromcresol purple } \dagger\end{array}$ & - & + & + & + & ND & ND & $\mathrm{ND}$ & ND & ND & ND & ND \\
\hline
\end{tabular}

* Data from this study.

$\dagger$ Bromcresol purple was tested at $0.018 \%$. 
species previously described as anaerobes have been shown to use $\mathrm{O}_{2}$ under microaerobic conditions and have been redefined as microaerophiles. For example, Wolinella succinogenes, using fumarate as terminal electron acceptor in anaerobiosis, was shown to use $\mathrm{O}_{2}$ at low concentrations (approximately $2 \% \mathrm{O}_{2}$ ) and was redefined as microaerophilic (Wolin et al., 1961; Jacobs \& Wolin, 1963a,b). Similarly, Wolinella recta, Wolinella curva and Bacteroides ureolyticus, bacteria described previously as anaerobic, using fumarate or nitrate as terminal electron acceptors, exhibited microaerophilic growth under $4-14 \% \mathrm{O}_{2}$ in liquid medium and $2-8 \%$ in solid medium (Han et al., 1991). Thus, the authors asserted that both species must be considered as anaerobic and microaerophilic rather than simply anaerobic. Strain M5 ${ }^{\mathrm{T}}$, which grew both under anaerobic and aerobic conditions, could be described as a facultatively anaerobic bacterium. However, the term 'facultative anaerobe' gives no information on the optimal $\mathrm{O}_{2}$ concentration for growth. Facultative anaerobes were defined as bacteria growing under aerobiosis with $\mathrm{O}_{2}$ as an electron acceptor and under anaerobiosis using another endogenous or exogenous electron acceptor. In the case of $E$. coli, the term 'facultative anaerobe' is appropriate because the species grows both under anaerobic and aerobic conditions and the cellular yield increases with $\mathrm{O}_{2}$ concentration, with no inhibition at atmospheric $\mathrm{O}_{2}$ concentrations. In contrast, the growth of strain $\mathrm{M}^{2}{ }^{2}$ was reduced under $\mathrm{O}_{2}$ concentrations higher than $5 \%$. Considering (i) the weak definition of the term 'facultative anaerobe' and (ii) the recent redefinition of some anaerobes as microaerophiles, we propose to combine the terms 'facultative anaerobe' and 'microaerophile' to designate the respiratory type of strain $\mathrm{M}^{\mathrm{T}}$ and to indicate clearly the preference of the isolate for low $\mathrm{O}_{2}$ concentrations.

Strain M5 ${ }^{\mathrm{T}}$ differed from $P$. acidipropionici, $P$. jensenii and $P$. thoenii in the range of substrates used (Table 1). L-Sorbose was fermented by strain $\mathrm{M} 5^{\mathrm{T}}$ only and not by $P$. acidipropionici, $P$. jensenii or $P$. thoenii. In contrast, aesculin was hydrolysed by $P$. acidipropionici, $P$. jensenii and $P$. thoenii, but not by strain $\mathrm{M}^{\mathrm{T}}$. Bromcresol purple inhibited specifically the growth of $P$. acidipropionici, $P$. jensenii and $P$. thoenii, but not the growth of strain $\mathrm{M} 5^{\mathrm{T}}$ (Table 2). The propionibacteria belong to the class Actinobacteria (Stackebrandt et al., 1997) and are divided into two main groups (Cummins \& Johnson, 1986, 1992), the 'cutaneous' propionibacteria, such as Propionibacterium acnes, $P$. granulosum and $P$. avidum, and the 'classical' or 'dairy' propionibacteria, such as $P$. acidipropionici, $P$. jensenii, $P$. thoenii and Propionibacterium freudenreichii. The cutaneous propionibacteria were isolated from human skin, whereas dairy propionibacteria were isolated mainly from dairy products. Although strain $\mathrm{M} 5^{\mathrm{T}}$ was not isolated from a dairy product, it is closely related to P. acidipropionici and clearly belongs to the phylogenetic cluster of 'dairy' propionibacteria. The presence of strain $\mathrm{M}^{\mathrm{T}}$ in olive mill wastewater is not surprising since it contains (i) a wide range of carbohydrates released from the olive pulp during the oilextraction process and (ii) organic acids, and in particular lactic acid, resulting from the fermentation of sugars by the lactic acid bacteria. It is well known that lactic and propionic acid bacteria may develop simultaneously in environments rich in sugars such as dairy by-products (Rehberger \& Glatz, 1998). Moreover, besides dairy products, classical propionibacteria have been isolated from soils (Van Niel, 1957; Prevot \& Fredette, 1966) and anaerobic digestors (Riedel \& Britz, 1993) and also from fermenting olives (Cancho et al., 1970, 1980; Vaughn, 1981). Our results, together with those of Cancho et al. (1970, 1980), suggest strongly that classical propionibacteria are also involved in the decomposition of organic compounds of olives. In addition, the presence of strain $\mathrm{M}^{\mathrm{T}}$, as a microaerophilic bacterium, validates the prior hypothesis that the design of the open-air reservoir permits the growth of microaerophilic bacteria.

On the basis of a polyphasic approach including both genotypic and phenotypic characteristics, we propose to designate strain $\mathrm{M} 5^{\mathrm{T}}$ as a new species of the genus Propionibacterium, Propionibacterium microaerophilum sp. nov.

\section{Description of Propionibacterium microaerophilum sp. nov.}

Propionibacterium microaerophilum (mi.cro.ae. ro'phi.lum. Gr. adj. mikros small, Gr. n. aer air; Gr. adj. philos loving; N.L. neut. adj. microaerophilum slightly air-loving).

Colonies on agar plates (basal medium) incubated under an atmosphere of $\mathrm{N}_{2} / \mathrm{O}_{2}(95: 5 \%, \mathrm{v} / \mathrm{v})$ are white and lens-shaped with smooth edges and $2-3 \mathrm{~mm}$ in diameter. Cells are Gram-positive, pleomorphic rods with rounded ends, non-motile, non-spore-forming, facultatively anaerobic, microaerophilic and catalasenegative. Although growth occurs under anaerobic and aerobic conditions, the optimum $\mathrm{O}_{2}$ concentration for growth is $5 \%$ in the gas phase of the culture. Nitrate is reduced to $\mathrm{N}_{2}$. The strain requires no complex nitrogen nutrients such as yeast extract, amino acids or peptides for growth and can grow with ammonium salts as the only nitrogen source. However, yeast extract stimulates growth. Under anaerobic conditions, large amounts of propionate, acetate and $\mathrm{CO}_{2}$ are produced from glucose or lactate fermentation. Lactate, formate and succinate can also be detected from glucose fermentation, depending on the $\mathrm{pH}$ or the medium composition. Neutrophilic and mesophilic. The $\mathrm{pH}$ for growth ranges from 4.5 to $9 \cdot 5$, with optimum growth at 7.0. The temperature for growth ranges from 20 to $45^{\circ} \mathrm{C}$, with optimum growth at $30{ }^{\circ} \mathrm{C}$. The DNA G $+\mathrm{C}$ content is $67.7 \pm 0.6 \mathrm{~mol} \%$. Results of 16S rRNA gene sequence analysis indicate that the isolate is related to members of genus Propionibacterium and is closely related to $P$. acidi- 
propionici (97.5\% similarity). DNA-DNA hybridization with this species showed $56 \%$ reassociation. Isolated from the decantation reservoir of olive mill wastewater of an olive oil factory in Raphèle-les-Arles (south of France). The type strain is $\mathrm{M}^{\mathrm{T}}$ ( = CNCM I$2360^{\mathrm{T}}=$ DSM $\left.13435^{\mathrm{T}}\right)$.

\section{ACKNOWLEDGEMENTS}

We thank P. Roger and T. Mechichi for revising the manuscript and M. Labat for helpful discussion. Financial assistance in part to B. K.C.P. from the Australian Research Council and to M.K. from the Ivorian Research Minister and from the Research Institute for Development (IRD) is gratefully acknowledged.

\section{REFERENCES}

Altschul, S. F., Madden, T. L., Schäffer, A. A., Zhang, J., Zhang, Z., Miller, W. \& Lipman, D. J. (1997). Gapped BLAST and PSI-BLAST: a new generation of protein database search programs. Nucleic Acids Res 25, 3389-3402.

Andrews, K. T. \& Patel, B. K. C. (1996). Fervidobacterium gondwanense sp. nov., a new thermophilic anaerobic bacterium isolated from nonvolcanically heated geothermal waters of the Great Artesian Basin of Australia. Int J Syst Bacteriol 46, 265-269.

Balch, W. E., Fox, G. E., Magrum, L. J., Woese, C. R \& Wolfe, R. S. (1979). Methanogens: re-evaluation of a unique biological group. Microbiol Rev 43, 260-296.

Balice, V., Boasis, G., Cera, O. \& Abbatichio, P. (1992). Indagine analitica sulle acque di vegetazione. Nota 1. Inquinamente 7 , 49-53.

Benson, D., Lipman, D. J \& Ostell, J. (1993). Genbank. Nucleic Acids Res 21, 2963-2965.

Cancho, F. G., Nosti Vega, M., Fernandez Diaz, M. \& Buzcu, N. J. Y. (1970). Especies de Propionibacterium relacionades con la zapateria. Factores que influen en su desarrollo. Microbiol Esp 23, 233-252.

Cancho, F. G., Navarro, L. R. \& de la Borbolla y Alcala, R. (1980). La formacion de acido propionic durante la conservacion de las aceitunas verdes de mesa. III. Microorganismos responsables. Grases Aceites 31, 245-250.

Cashion, P., Holder-Franklin, M. A., Mc Cully, J. \& Franklin, M. (1977). A rapid method for the base ratio determination of bacterial DNA. Anal Biochem 81, 461-466.

Charfreitag, O., Collins, M. D. \& Stackebrandt, E. (1988). Reclassification of Arachnia propionica as Propionibacterium propionicus comb. nov. Int J Syst Bacteriol 38, 354-357.

Cord-Ruwisch, R. (1985). A quick method for the determination of dissolved and precipitated sulfides in cultures of sulfatereducing bacteria. J Microbiol Methods 4, 33-36.

Cummins, C. S. \& Johnson, J. L. (1986). Genus I. Propionibacterium Orla-Jensen 1909. In Bergey's Manual of Systematic Bacteriology, vol. 2, pp. 1346-1353. Edited by P. H. A. Sneath, N. S. Mair, M. E. Sharpe \& J. G. Holt. Baltimore: Williams \& Wilkins.

Cummins, C. S \& Johnson, J. L. (1992). The genus Propionibacterium. In The Prokaryotes, vol. 1, pp. 834-849. Edited by A. Balows, H. G. Trüper, M. Dworkin, W. Harder \& K.-H. Schleifer. New York: Springer.

De Ley, J., Cattoir, H. \& Reynaerts, A. (1970). The quantitative measurement of DNA hybridization from renaturation rates. Eur J Biochem 12, 133-142.

Delwiche, E. A. (1949). Vitamin requirements of the genus Propionibacterium. J Bacteriol 58, 293-398.

De Vries, W., Aleem, M. I. H., Hemrika-Wagner, A. \& Stouthamer, A. H. (1977). The functioning of cytochrome $b$ in the electron transport to fumarate in Propionibacterium freudenreichii and Propionibacterium pentosaceum. Arch Microbiol 112, 271-276.

Escara, J. F. \& Hutton, J. R. (1980). Thermal stability and renaturation of DNA in dimethyl sulfoxide solutions: acceleration of the renaturation rate. Biopolymers 19, 1315-1327.

Felsenstein, J. (1993) PHYLIP (Phylogenetic Inference Package) version 3.51c. Distributed by the author. Department of Genetics, University of Washington, Seattle, WA, USA.

Ferguson, D. A., Jr \& Cummins, C. S. (1978). Nutritional requirements of anaerobic coryneforms. J Bacteriol 135, 858-867.

Hamdi, M., Festino, C. \& Aubart, C. (1992). Anaerobic digestion of olive mill wastewater in fully mixed reactors and in fixed film reactors. Process Biochem 27, 37-42.

Han, Y.-H., Smibert, R. M. \& Krieg, N. R. (1991). Wolinella recta, Wolinella curva, Bacteroides ureolyticus, and Bacteroides gracilis are microaerophiles, not anaerobes. Int J Syst Bacteriol 41, 218-222.

Harborne, J. B. (1980). Plant phenolics. In Secondary Plant Products, pp. 329-402. Edited by E. A. Bell \& B. V. Charlwood. New York: Springer.

Holland, K. T., Greenman, J. \& Cunliffe, W. J. (1979). Growth of cutaneous propionibacteria on synthetic medium; growth yields and exoenzyme production. J Appl Bacteriol 47, 383-394.

Huß, V. A. R., Festel, H. \& Schleifer, K. H. (1983). Studies on the spectrophotometric determination of DNA hybridization from renaturation rates. Syst Appl Microbiol 4, 184-192.

Jacobs, N. J. \& Wolin, M. J. (1963a). Electron-transport system of Vibrio succinogenes. I. Enzymes and cytochromes of the electron-transport system. Biochim Biophys Acta 69, 18-28.

Jacobs, N. J. \& Wolin, M. J. (1963b). Electron-transport system of Vibrio succinogenes. II. Inhibition of electron-transport by 2heptyl-4-hydroxyquinoline N-oxide. Biochim Biophys Acta 69, 29-39.

Jahnke, K. D. (1992). Basic computer program for evaluation of spectroscopic DNA renaturation from GILFORD system 2600 spectrophotometer on a PC/XT/AT type personal computer. $J$ Microbiol Methods 15, 61-73.

Jahnke, K. D. \& Bahnweg, G. (1986). Assessing natural relationships in the basidiomycetes by DNA analysis. Trans Br Mycol Soc 87, 175-191.

Jukes, T. H. \& Cantor, C. R. (1969). Evolution of protein molecules. In Mammalian Protein Metabolism, pp. 211-232. Edited by H. N. Munro. New York: Academic Press.

Kusano, K., Yamada, H., Niwa, M. \& Yamasato, K. (1997). Propionibacterium cyclohexanicum sp. nov., a new acid-tolerant $\omega$-cyclohexyl fatty acid-containing propionibacterium isolated from spoiled orange juice. Int J Syst Bacteriol 47, 825-831.

Maidak, B. L., Olsen, G. J., Larsen, N., Overbeek, R., McCaughey, M. J. \& Woese, C. R. (1996). The ribosomal database project (RDP). Nucleic Acids Res 24, 82-85.

Marty, D., Bertrand, J.-C. \& Caumette, P. (1988). Les métabolismes bactériens dans les systèmes sédimentaires marins. In Micro-organismes dans les Écosystèmes Océaniques, pp. 101-151. Edited by M. Bianchi, D. Marty, J.-C. Bertrand, P. Caumette \& M. Gauthier. Paris: Masson. 
Meile, L., Dasen, G., Miescher, S., Stierli, M. \& Teuber, M. (1999). Classification of propionic acid bacteria and approaches to applied genetics. Lait 79, 71-78.

Mesbah, M., Premachandran, U. \& Whitman, W. B. (1989). Precise measurement of the $\mathrm{G}+\mathrm{C}$ content of deoxyribonucleic acid by high-performance liquid chromatography. Int $J$ Syst Bacteriol 39, 159-167.

Prevot, A.-R. \& Fredette, V. (1966). Manual for the Classification and Determination of the Anaerobic Bacteria. Philadelphia: Lea $\&$ Febiger.

Pritchard, G. G., Wimpenny, J. W. T., Morris, H. A., Lewis, M. W. A. \& Hughes, D. E. (1977). Effect of oxygen on Propionibacterium shermanii grown in continuous culture. J Gen Microbiol 102, 223-233.

Redburn, A. C. \& Patel, B. K. C. (1993). Phylogenetic analysis of Desulfotomaculum thermobenzoicum using polymerase chain reaction-amplified 16S rRNA-specific DNA. FEMS Microbiol Lett 113, 81-86.

Rehberger, J. L. \& Glatz, B. A. (1998). Response of cultures of Propionibacterium to acid and low $\mathrm{pH}$ : tolerance and inhibition. J Food Protect 61, 211-216.

Riedel, K.-H. \& Britz, T. J. (1993). Propionibacterium species diversity in anaerobic digestors. Biodivers Conserv 2, 400-411.

Sayadi, S. \& Ellouz, R. (1993). Screening of white rot fungi for the treatment of olive mill wastewater. J Chem Technol Biotechnol 57, 141-146.

Schaal, K. P. (1986). Genus Arachnia Pine and Georg 1969. In Bergey's Manual of Systematic Bacteriology, vol. 2, pp. 1332-1342. Edited by P. H. A. Sneath, N. S. Mair, M. E. Sharpe \& J. G. Holt. Baltimore: Williams \& Wilkins.

Sone, N. (1972). The redox reactions in propionic acid fermentation. I. Occurrence and nature of an electron transfer system in Propionibacterium arabinosum. $J$ Biochem 71, 931-940.

Stackebrandt, E., Rainey, F. A. \& Ward-Rainey, N. L. (1997). Proposal for a new hierarchic classification system, Actinobacteria classis nov. Int J Syst Bacteriol 47, 479-491.

Stanier, R. Y., Aldeberg, E. A. \& Ingraham, J. L. (1976). In The Microbial World, p. 853. Englewood Cliffs, NJ : Prentice-Hall.

Van Niel, C. B. (1957). Genus Propionibacterium. In Bergey's Manual of Determinative Bacteriology, 7th edn, pp. 569-576. Edited by R. S. Breed, E. G. D. Murray \& N. R. Smith. Baltimore: Williams \& Wilkins.

Vaughn, R. H. (1981). Lactic acid fermentation of cabbage, cucumbers, olives, and other products. In Prescott \& Dunn's Industrial Microbiology, 4th edn, pp. 220-224. Edited by G. Reed. Westport, CT: Avipublishing Co.

Weinberg, M., Nativelle, R. \& Prevot, A. R. (1937). Les Microbes Anaérobies. Paris: Masson \& Co. Cited by Senez, J. C. (1968) Microbiologie Générale, pp. 193. Paris: Deren and Co.

Winker, S. \& Woese, C. R. (1991). A definition of the domain Archaea, Bacteria and Eucarya in terms of small subunit ribosomal RNA characteristics. Syst Appl Microbiol 13, 161-165.

Wolin, M. J., Wolin, E. A. \& Jacobs, N. J. (1961). Cytochromeproducing anaerobic vibrio, Vibrio succinogenes, sp. n. $J$ Bacteriol 81, 911-917.

Wood, H. G. (1981). Metabolic cycles in the fermentation by propionic acid bacteria. Curr Top Cell Regul 18, 255-287.

Ye, K., Shijo, M., Miyano, K. \& Shimizu, K. (1999). Metabolic pathway of Propionibacterium growing with oxygen: enzymes, ${ }^{13} \mathrm{C}$ NMR analysis, and its application for vitamin $\mathrm{B}_{12}$ production with periodic fermentation. Biotechnol Prog 15, 201-207. 